В.Є. КОВАЛЕНКО

\title{
ВЗАЕМОДІЯ ЗАКЛАДІВ ПОЗАШКІЛЬНОЇ ТА ЗАГАЛЬНОЇ СЕРЕДНЬОЇ ОСВІТИ У ПРОЦЕСІ СОЦІАЛІЗАЦІЇ ДІТЕЙ 3 ІНТЕЛЕКТУАЛЬНИМИ ПОРУШЕННЯМИ
}

\author{
(C) Коваленко В.С., 2019 \\ https://orcid.org/0000-0002-7792-4653 \\ http://doi.org/10.34142/2312-2471.2019.61.09
}

У статті розглядається проблема взаємодії закладів позашкільної та загальної середньої освіти у процесі сочіалізащії дітей з інтелектуальними порушеннями. Уточнено сутність основних понять, охарактеризовано основні інститути соціалізації, встановлені основні логічні зв'язки між ними. Соціалізація дитини з інтелектуальними порушеннями розглядається як процес $i$ результат засвоєння знань $і$ навичок суспільного жстття, формування загальноприйнятих стереотипів, норм і правил поведінки, освоєння прийнятих в суспільстві цүіннісних орієнтацій, повноцінного включення в стандартні форми соціальної взаємодї та комунікації. Це в сукупності повинно забезпечити незалежний спосіб життя, ефективну соціальну та культурну інтеграцію. Встановлено, щуо в ситуації цілеспрямованого позитивного соціалізуючого впливу суспільства в осіб з інтелектуальними порушеннями реально сформувати соціально-значущуі якості (інтереси, ияінності, изіннісні орієнтації $і$ изілі), які впливатимуть на самодетермінацію особистості на основі ї̈ внутрішньої $i$ зовнішньої активності. Компенсаторну функцію в процесі виховання дітей з інтелектуальними порушеннями мають виконувати заклади позашкільної освіти, орієнтовані на соціальне виховання, формування сочіально адаптованої особистості. Проаналізовано взаємодію закладів позашкільної $і$ загальної середньої освіти як соціальну систему грамотного педагогічного впливу на сочіалізацію дитини з інтелектуальними порушеннями. Формами організаиії взаємодії закладів позашкільної $i$ загальної середньої освіти у процесі соціалізациї дітей з інтелектуальними порушеннями $\epsilon$ створення студентських об'єднань на базі закладів загальної середньої освіти художньо-естетичного, мистецького, туристсько-краєзнавчого, екологонатуралістичного, спортивного, сочуіально-реабілітаційного та оздоровчого напрямів позашкільної освіти. Важливою умовою для цуього є модифікація освітніх програм творчих об'єднань позашкільної освіти відповідно до потенційних можливостей і потреб дітей з інтелектуальними порушеннями.

Ключові слова: сочіалізачія, діти з інтелектуальними порушеннями, позашкільна освіта, заклад загальної середньої освіти, заклад спечіальної освіти для дітей з інтелектуальними порушеннями. 


\section{Kovalenko V. Ye. Interaction of Out-school and General Secondary} Education Institutions in the Process of Children' Socialization with Intellectual Disorders

The article deals with the problem of interaction of out-of-school and general secondary education institutions in the process of children' socialization with intellectual disabilities. The essence of the basic concepts is clarified, the main institutions of socialization are characterized, the main logical relationships between them are established. The socialization of a child with intellectual disabilities is considered as a process and result of the assimilation of knowledge and skills in social life, the development of generally accepted stereotypes, norms and rules of behavior, the development of value orientations adopted in a society, full inclusion in the standard forms of social interaction and communication, in the aggregate, it should ensure an independent lifestyle, effective social and cultural integration. It has been established that in a situation of purposeful positive socializing public in persons with intellectual disabilities, it is possible to form socially significant qualities (interests, values, value orientations and goals) that will affect the selfdetermination of an individual based on his/her internal and external activity. The compensatory function in the process of raising children with intellectual disabilities should be performed by such institutions of socialization as out-of-school education institutions focused on social education, the formation of a socially adapted personality. The article analyzes the integration of out-of-school and general secondary education institutions as a social system of competent pedagogical influence on the socialization of a child with intellectual disabilities. Appropriate forms of organizing the interaction of out-of-school and general secondary education institutions in the process of socialization of children with intellectual disabilities are the creation of child's associations on the basis of special institutions of general secondary education of artistic and aesthetic, artistic, tourism and local history, environmental and naturalistic, physical culture and sports, social rehabilitation and health improvement in directions of out-of-school education. An important condition for this is the modification of the educational programs for children associations of out-of-school education in accordance with the potential capabilities and needs of children with intellectual disabilities.

Key words: socialization, children with intellectual disabilities, out-of-school education, general secondary education, special education for children with intellectual disabilities.

Постановка проблеми. Удосконалення сучасної системи освіти дітей з особливими освітніми потребами відповідно до принципів гуманізації та індивідуалізації передбачає пошук ефективних шляхів забезпечення їх успішної соціалізації та соціальної адаптації. Важливу роль у процесі гуманізації виконує позашкільна освіта, яка спрямована на розвиток здібностей дітей з урахуванням їх індивідуальних потреб та інтересів, зокрема у соціалізації, професійному визначенні та інтеграції в суспільство. І. Мосякова стверджує, що позашкільна 
освіта $\epsilon$ унікальним середовищем спілкування та засобом формування ціннісних установок у вихованців, яке сприяє позитивній соціалізації та професійному самовизначенню. Основою позашкільної освіти $є$ цілісний особистісний розвиток дитини (Мосякова I., 2018, с. 5).

Зважаючи на соціальну значущість i вагомі досягнення у справі виховання дітей, система позашкільної освіти та окремі аспекти діяльності закладів позашкільної освіти щодо навчання, виховання, соціального становлення особистості були предметом наукового аналізу вітчизняних i зарубіжних фахівців (О. Безпалька, І. Беха, О. Биковської, В. Вербицького, А. Золотарьової, Б. Купріянова, О. Лєбедєва, О. Литовченко, Л. Логінової, Г. Пустовіта, Т. Сущенко).

Обгрунтовано теоретико-методологічні і дидактичні засади позашкільної освіти та виховання (Г. Пустовіт), досліджено теоретико-методичні основи позашкільної освіти в Україні (О. Биковська), охарактеризовано психологічний супровід духовного розвитку молоді, виховання творчої особистості (Е. Помиткін, В. Рибалка); професійне самовизначення старшокласників (В. Мачуський), формування соціального досвіду, виховання соціальних якостей учнів (П. Кендзьор, О. Кононко, О. Литовченко, С. Мартова, T. Окушко, О. Савченко, І. Стародубцева). Вчені наголошують про спрямованість позашкільної освіти України на формування соціальних якостей особистості, набуття соціальних знань, соціального досвіду та загалом соціалізації дитини.

Аналіз останніх досліджень і публікацій. Проблему соціалізації особистості досліджували в контексті навчання й виховання (М. Боришевський, Л. Виготський, Г. Костюк, С. Максименко, Ж. Піаже); вікові особливості перебігу процесу соціалізації (Л. Божович, І. Кон, Н. Чепелєва, Ю. Швалб); проблеми взаємодії особистості й освітнього середовища (Л. Виготський, В. М'ясищев, В. Семиченко, М. Савчин, М. Тоба, Т. Щербан); аналіз структурно-функціонального апарату соціалізації (В. Агеєв, Г. Андреєва, Г. Балл, А. Дмитренко, М. Корнєв, В. Москаленко, Ш. Надірашвілі); соціалізацію особистості в сім'і (Н. Абдюкова, Б. Заззо, Г. Крайг, Т. Кравченко), в колективі (М. Казакіна, Р. Нємов, А. Петровський, С. Рубінштейн). Маючи різні погляди на зміст поняття «соціалізація», дослідники одностайні в тому, що цей термін використовується для позначення процесу, в ході якого людська істота 3 певними біологічними задатками набуває соціальних якостей, що $\epsilon$ необхідними їй для життєдіяльності у суспільстві.

У спеціальних психолого-педагогічних дослідженнях проблему соціалізації дітей з особливими освітніми потребами досліджували Віт. Бондар, Ю. Бистрова, І. Білозерська, Т. Вісковатова, А. Висоцька, В. Засенко, О. Глоба, Н. Лавриченко, Н. Макарчук, О. Маллер, С. Максименко, О. Мамічева, К. Островська, Л. Руденко, В. Синьов, С. Синьова, М. Супрун, І. Татьянчикова, С. Трикоз, Л. Фомічова, О. Хохліна, А. Шевцов, М. Шеремет. Вчені констатують, що саме соціалізація є основою особистісного зростання дитини та іiі підготовки до самостійної життєдіяльності. 
Науковці звертають увагу на типові труднощі процесу соціалізації дітей 3 особливими освітніми потребами, що виникають внаслідок порушень (дивергенції) соціального та біологічного профілів розвитку, обмеженої мобільності, бідності контактів з однолітками і дорослими (Л. Виготський, В. Синьов, А. Каплієва).

Особливо виразно труднощі соціалізації виявляються у дітей 3 інтелектуальними порушеннями, адже їх специфічні закономірності розвитку, такі як: уповільнення темпу вікового розвитку, зниження швидкості прийому та обробки інформації, порушення пізнавальної активності та пізнавальної діяльності, недорозвинення всіх форм предметної діяльності, порушення мовленнєвої діяльності i недоліки словесного опосередкування, комунікативної, пізнавальної та регулюючої функцій мови, призводять до збільшення строків формування та звуження запасу знань і уявлень про навколишній світ і про себе, уповільнюють темпи формування вищих психічних функцій, збіднюють соціальний досвід дитини та суттєво ускладнюють процес соціальної адаптації.

У Законі України «Про позашкільну освіту» та науковій літературі (А. Висоцька, І. Гладченко, А. Капська, Р. Клайрис, О. Литовченко, М. Супрун, I. Татьянчикова, О. Хохліна, А. Шарланова) сформульована ідея про важливість застосування ресурсів позашкільної освіти як дієвого чинника виховання дітей 3 інтелектуальними порушеннями, покликаного сприяти їх успішній соціалізації та соціальній адаптації. Ж. Петрочко наголошує на значенні соціально-педагогічної діяльності, що здійснюється 3 метою оптимізації виховних можливостей соціальних інститутів, зокрема, закладів позашкільної освіти, шляхом активного залучення дітей до соціально-виховного середовища (Петрочко Ж., 2010, с. 223). Водночас, висвітлені аспекти не дають цілісного уявлення про психолого-педагогічні умови використання позашкільної освіти як фактора соціалізації дітей з інтелектуальними порушеннями.

Це актуалізує необхідність визначення й запровадження в педагогічну практику психолого-педагогічних умов, які б, з одного боку, забезпечували дієвість виховання, а 3 іншого, сприяли успішному перебігу загального соціалізаційного процесу. Важливе місце серед таких умов належить взаємодії закладів позашкільної та загальної середньої освіти, яка сприяє узгодженню i взаємопідсиленню виховних впливів, що надходять від педагогів як провідних агентів соціалізації.

Виділення невирішених раніше частин загальної проблеми. Незважаючи на наявні дослідження 3 обгрунтування впливу позашкільної освіти на соціалізацію дітей, відповідна наукова розвідка $є$ актуальною.

По-перше, маємо підстави говорити про високий рівень актуального стану проблеми покращення рівня соціалізованості дітей з інтелектуальними порушеннями, які здобувають освіту в закладі загальної середньої освіти 3 інклюзивним навчанням та у спеціальній школі, що вимагає обгрунтування виховних можливостей цієї ланки освіти, які на сучасному етапі $\epsilon$ потенційними. 
По-друге, соціокультурні зміни, сучасний розвиток спеціальної психолого-педагогічної науки зумовлюють необхідність постійного розвитку та модернізації всіх ланок освіти України, зокрема позашкільної освіти, іiі соціалізуючого потенціалу.

По-третє, умовою не лише теоретичної, а й практичної та соціальної значущості результату відповідного дослідження $\epsilon$ взаємодія закладів позашкільної освіти з іншими інституціями в аспекті соціалізації особистості. Актуальність зазначеної проблеми, ऑiі недостатне теоретичне й експериментальне вивчення зумовили вибір теми наукової статті «Взаємодія закладів позашкільної та загальної середньої освіти у процесі соціалізації дітей 3 інтелектуальними порушеннями».

Формування цілей статті. Зважаючи на вище сказане, метою нашої роботи є аналіз напрямів взаємодії закладів позашкільної та загальної середньої освіти та визначення умов ефективного впливу на соціалізацію особистості дитини з інтелектуальними порушеннями.

Відповідно до поставленої мети передбачено виконання завдань: з'ясувати сутність поняття «соціалізація»; розглянути позашкільну освіту як інститут соціалізації дітей з інтелектуальними порушеннями; визначити шляхи взаємодії закладів позашкільної освіти із закладами загальної середньої та спеціальної освіти як інститутів соціалізації дітей 3 інтелектуальними порушеннями.

Виклад основного матеріалу дослідження. Важливою в сучасних педагогічних, психологічних, соціологічних та філософських дослідженнях $\epsilon$ проблема соціалізації. В. Москаленко вказує, що це процес у якому людина набуває соціальних якостей, необхідних для соціальної адаптації у суспільстві, в процесі якого відбувається становлення соціального досвіду, забезпечується спадкоємність історичного розвитку. Вперше термін «соціалізація» вжив Г. Тард для позначення процесу інтеріоризації соціальних норм шляхом соціальної взаємодії (Циба В., 2000, с. 114-115). У наукову систему понять термін «соціалізація» увів американський соціолог Ф. Гідінгстон наприкінці XIX ст., який тлумачив його як «процес розвитку соціальної природи людини» (Капська А., 2001).

Упродовж останнього сторіччя наукові дослідження проблеми соціалізації здійснювались як міждисциплінарний науковий напрям, що обумовлює різноманіття підходів до його вивчення на основі філософських, соціологічних, психологічних, педагогічних поглядів.

У філософському контексті (П. Бергер, Р. Будон, М. Вебер, Ф. Гіддінс, Е. Дюркгейм, Т. Лукман, Р. Мертон, Т. Парсонс, П. Сорокін, Ю. Хабермаса, П. Штомпка, А. Шюц) соціалізація розглядається як утілення в окремому суб'єкті тієї соціальної реальності, в яку він занурений, тобто соціалізація - це процес, що протікає між людиною та суспільством і перетворює індивідуальне буття в особистісне. При цьому суб'єкт $\epsilon$ реально діючою особою, котра у сумісній з іншими суб'єктами діяльності організовує, визначає і конструює процес власної соціалізації (М. Вебер, Г. Ляйбниць). 
У соціологічному контексті проблему соціалізації досліджували $€$. Ануфрієв, В. Афанасьєв, Я. Гілінський, В. Дмитрієнко, Л. Зеленов, Л. Коган, I. Кон, О. Кравченко, Ю. Левада, І. Мартинюк, В. Немирівський, Г. Осипов, А. Радугин, Х. Сабіров, Ж. Тощенко, С. Фролов. Науковці трактують поняття «соціалізації» як процесу формування основних параметрів людської особистості (свідомості, почуттів, здібностей і т.д.) під час виховання та навчання, засвоєння соціальних ролей, у результаті чого людина перетворюється в члена суспільства, успадковуючи історичний досвід. К. Левіт (2007) визначає соціалізацію як процес засвоєння й активного відтворення індивідом соціокультурного досвіду (соціальних норм, цінностей, зразків поведінки, ролей, установок, звичаїв, культурної традиції, колективних уявлень і вірувань і т. д.).

У психології соціалізація розглядається як здатність індивіда включатися в цілеспрямовану діяльність суб'єктів різних соціальних інституцій завдяки інтеріоризації системи соціальних настанов (Н. Дембицька, Т. Карабін, М. Коць, О. Лютак, В. Москаленко та ін.). За спостереженнями В. Москаленка на індивідуальному рівні соціалізація особистості включає такі процеси: взаємодію, вплив, набуття досвіду, окультурення (Москаленко В., 2008). Бути соціалізованим означає бути залученим до норм і цінностей суспільства, володіти вміннями досягнення власних цілей без неусвідомленого нанесення шкоди іншим людям (С. Розум).

У соціальній психології соціалізація особистості практично ототожнюється із соціальною адаптацією в широкому іiі розумінні. Соціальна адаптація $\epsilon$ інтегративним показником стану людини (Л. Божович, Л. Виготського, Д. Ельконіна, О. Леонтьєва, М. Лісіної), який віддзеркалює ії можливості виконувати певні біосоціальні функції: адекватне сприйняття соціальної дійсності і власного організму; адекватну систему взаємин i стосунків з оточенням; спроможність до праці, навчання, дозвілля; здатність до самообслуговування і взаємообслуговування в сім'ї та колективі; адаптивність поведінки відповідно до рольових очікувань інших.

У педагогічних дослідженнях соціалізація визначається як процес призвичаєння людини для подолання суперечностей, що постають перед нею у соціальному житті (Б. Вульфов); процес передачі дитині соціального досвіду, який містить суспільні уявлення, ідеали, цінності та норми, алгоритми форм поведінки з метою формування в неї необхідної сукупності соціальних ролей (Н. Лавриченко).

A. Реан i Я. Коломінський дотримуються розуміння поняття «соціалізації» ширшого за виховання, вказуючи, що виховання являє собою керований і цілеспрямований процес соціалізації, в той час як соціалізація може здійснюватися у вигляді як цілеспрямованого, так і нерегульованого процесів (А. Реан, Я. Коломінський, 1999). Соціалізація - це особливий процес включення дитини в суспільство, процес і результат засвоєння, активного відтворення індивідом соціального досвіду. Він може відбуватися як стихійно, так і цілеспрямовано. 
Міждисциплінарний аналіз проблеми соціалізації особистості вказує на двосторонне розуміння його сутності. 3 однієї сторони особистість засвоює соціальний досвід у процесі входження до системи існуючих соціальних зв'язків, з іншої - є діяльнісним суб' єктом, що зберігає і розвиває тенденцію до автономії, формування власної позиції, неповторної індивідуальності. Тож, єдність процесів адаптації, інтеграції і самореалізації забезпечує оптимальний розвиток особистості у їі взаємодії з середовищем, а їх перетин і є суттю соціалізації.

Наявність інтелектуальних порушень вносить своєрідність у процес становлення такої дитини як особистості, а їх негативні соціальні наслідки значно ускладнюють процес соціалізації. Соціалізація дитини 3 інтелектуальними порушеннями розглядається як процес і результат засвоєння знань і навичок суспільного життя, вироблення загальноприйнятих стереотипів, норм i правил поведінки, освоєння прийнятих в суспільстві ціннісних орієнтацій, повноцінного включення в стандартні форми соціальної взаємодії та комунікації, що в сукупності повинно забезпечити незалежний спосіб життя, ефективну соціальну та культурну інтеграцію (І. Гладченко, М.О. Супрун, А.В.Висоцька, 2014, с. 26).

Для осіб 3 інтелектуальними порушеннями характерні наступні особливості процесу інтеріоризації (особливо в ситуації спонтанного розвитку): низький рівень інтересу до процесів і явищ, що відбуваються в соціальному житті (що істотно ускладнює процес запозичення інформації та присвоєння елементів культури), зниження здатності до засвоєння інформації, особливо поданої в словесно-логічній формі. Проте, не дивлячись на труднощі формування уявлень і засвоєння знань, умінь, навичок, зразків поведінки, затримку в розвитку різних видів діяльності, діти 3 інтелектуальними порушеннями все ж мають можливості для відносно успішного перебігу екстеріорізаціі та соціальної адаптації. Тому в ситуації цілеспрямованого позитивного соціалізуючого впливу суспільства в осіб з інтелектуальними порушеннями реально сформувати соціально-значущі якості (інтереси, цінності, ціннісні орієнтації і цілі), які впливатимуть на самодетермінацію

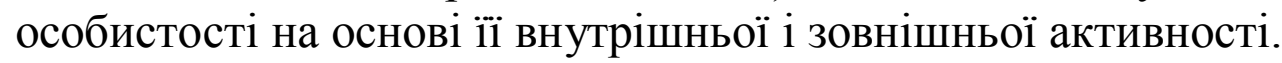

За спостереженнями А. Мудрик (2009), провідними мікрофакторами соціалізації дитини є заклади освіти, в яких здійснюється соціальне виховання. Мікрофактори впливають на розвиток дитини через «агентів соціалізації» осіб, у безпосередній взаємодії з якими проходить ï життя та які створюють мікроклімат, що стихійно або цілеспрямовано впливають на соціальний розвиток особистості. За таких умов суб'єкти впливу називаються інститутами соціалізації або соціальними інститутами.

Тож, освітнє середовище закладу загальної середньої, спеціальної та позашкільної освіти доцільно розглядати як інститути соціалізації, що $\epsilon$ складно організованими системами, які дають змогу вирішувати не лише освітні, але й низку соціально-психологічних завдань (залучення дітей до системи певних норм і цінностей, формування у них відповідних навичок $\mathrm{i}$ 
вмінь, розвиток і примноження контактів з іншими людьми в умовах спільної діяльності, збагачення суспільним досвідом тощо).

Результати експериментального дослідження соціалізації дітей 3 інтелектуальними порушеннями Д. Єрмолаєва (2013) дозволили сформулювати висновок, що успішність процесів інтеріоризації, екстеріорізаціі і соціальної адаптації таких людей багато в чому залежить від планомірного впливу освітнього середовища.

При цьому більш успішна соціальна адаптація людей 3 легкими інтелектуальними порушеннями можлива не тільки в сфері фізичної праці, але i в таких видах діяльності, як спорт, рукоділля, живопис, музика, театр та ін. Саме тому, компенсаторну функцію у процесі виховання дітей iз інтелектуальними порушеннями мають здійснювати такі інститути соціалізації як заклади позашкільної освіти, що орієнтовані на соціальне виховання, формування соціально адаптованої особистості.

Саме взаємодія закладу позашкільної освіти та закладу загальної середньої освіти 3 інклюзивним навчанням дітей 3 інтелектуальними порушеннями або спеціальним закладом освіти повинна забезпечити корекційне виховання дітей 3 інтелектуальними порушеннями, формування особистості, підготовленої до життя, посильної участі в суспільно корисній праці; особистості, здатної до успішної адаптації до умов і стилю життя суспільства, в якому вона перебуває.

Професіональний підхід до налагодження взаємодії закладів позашкільної та загальної середньої освіти у процесі соціалізації дітей з інтелектуальними порушеннями починається 3 усвідомлення їхньої спільної мети, поетапного переходу від стадії зацікавленості до стадії планування конкретних шляхів партнерства.

Наведемо орієнтовний перелік форм взаємодії закладів позашкільної та загальної середньої освіти у процесі соціалізації дітей 3 інтелектуальними порушеннями:

- створення учнівських об'єднань дітей з інтелектуальними порушеннями на базі спеціальних закладів загальної середньої освіти художньо-естетичного, мистецького, туристсько-краєзнавчого, еколого-натуралістичного, фізкультурно-спортивного, соціально-реабілітаційного та оздоровчого напрямів позашкільної освіти в організаційній формі гурткової роботи;

- організація на базі закладів загальної середньої освіти 3 інклюзивним навчанням дітей з інтелектуальними порушеннями філій закладів позашкільної освіти (художньо-естетичного, мистецького, туристсько-краєзнавчого, екологонатуралістичного, спортивного, соціально-реабілітаційного та оздоровчого напрямів позашкільної освіти);

- підготовка та проведення масових просвітницьких заходів;

- проведення літніх екологічних і краєзнавчих експедицій, організація таборів праці та відпочинку.

Найважливішим завданням участі дітей із інтелектуальними порушеннями в творчих об’єднаннях закладів позашкільної освіти $\epsilon$ 
розширення сфери їх самостійності, під якою розуміється подолання ними ізольованості, розвиток навичок комунікації та вміння освоювати i застосовувати без безпосередньої сторонньої допомоги знання і навички для вирішення повсякденних завдань. Це можливо лише за умови модифікації/адаптації програм творчих об'єднань. Активні форми діяльності при освоєнні програми позашкільної освіти націлюють дітей із інтелектуальними порушеннями на збагачення i розширення їх соціальної включеності у вирішення проблем міжособистісної взаємодії.

Висновки. Отже, залучення дітей з інтелектуальними порушеннями до позашкільної освіти здійснює на них соціалізуючий вплив, розширює можливості для самоствердження i самореалізації, соціальної адаптації, розширює комунікативні зв'язки, можливості їх інтелектуального і фізичного розвитку; в зв'язку з чим зростає можливість їх прийняття здоровими однолітками в єдиному дитячо-дорослому співтоваристві.

Доцільними формами організації взаємодії закладів позашкільної та загальної середньої освіти у процесі соціалізації дітей 3 інтелектуальними порушеннями є створення учнівських об'єднань на базі спеціальних закладів загальної середньої освіти художньо-естетичного, мистецького, туристськокраєзнавчого, еколого-натуралістичного, фізкультурно-спортивного, соціальнореабілітаційного та оздоровчого напрямів позашкільної освіти.

Доцільною формою взаємодії закладів позашкільної та загальної середньої освіти 3 інклюзивним навчанням $\epsilon$ створення філій закладів позашкільної освіти (художньо-естетичного, мистецького, туристськокраєзнавчого, еколого-натуралістичного, спортивного, соціальнореабілітаційного та оздоровчого напрямів позашкільної освіти) та включення дітей 3 інтелектуальними порушеннями до творчих об'єднань дітей 3 нормотиповим розвитком.

Важливою умовою при цьому є модифікація освітніх програм учнівських об'єднань напрямів позашкільної освіти відповідно до потенційних можливостей та потреб дітей 3 інтелектуальними порушеннями. Варто зазначити, що отримані знання i вміння дітьми 3 інтелектуальними порушеннями в системі позашкільної освіти можуть в подальшому житті таких дітей бути не тільки дозвіллям, а й профілюванням їх професійно-трудової соціалізації.

Перспективи подалыших розробок вбачаємо в розробці освітніх програм туристсько-краєзнавчого та соціально-реабілітаційного напрямів позашкільної освіти для дітей з інтелектуальними порушеннями.

\section{Лimepamypa}

1. Гладченко I., Супрун М., Висоцька А. Соціалізація дитини 3 обмеженими розумовими можливостями в сучасному освітньому вимірі. Київ: Інститут спеціальної педагогіки, 2014. 214 с.

2. Ермолаев Д.О. Социализация детей с интеллектуальными недостатками развития. Фундаментальные исследования. 2013. № 9-1. С. 32-36. 
URL: http://www.fundamental-research.ru/ru/article/view?id=32172 (дата звернення: 29.08.2020).

3. Капська А. Й. Соціальна робота: деякі аспекти роботи з дітьми та молоддю. Київ, 2001. С. 21.

4. Мойсеюк Н. Педагогіка. Вінниця: Універсум-Вінниця, 1998. 348 с.

5. Москаленко В.В. Соціальна психологія. Київ: Центр учбової літератури, 2008. 688c.

6. Мосякова I. Ю. Концептуальні основи модернізації змісту позашкільної освіти: практико орієнтований посібник. Київ : Педагогічна думка, 2018. Ч.1. $121 \mathrm{c.}$

7. Москаленко В. В. Соціалізація особистості: монографія. Київ :Фенікс, 2013. $540 \mathrm{c}$.

8. Мудрик А.В. Социальная педагогика. Москва : Академия, 2009. 224 с.

9. Петрочко Ж. В. Дитина в складних життєвих обставинах: соціальнопедагогічне забезпечення прав: монографія. Рівне, 2010. 368 с.

10.Реан А. Психология человека от рождения до смерти. Москва: Издательство АСТ, 2015. 656 с.

11.Циба В. Г. Соціологія особистості: системний підхід (соціальнопсихологічний аналіз). Київ : МАУП, 2000. 217 с.

\section{References}

1. Hladchenko, I., Suprun, M., Vysotska, A. (2014) Sotsializatsiia dytyny z obmezhenymy rozumovymy mozhlyvostiamy $\mathrm{v}$ suchasnomu osvitnomu vymiri. Kyiv: Instytut spetsialnoi pedahohiky, $214 \mathrm{~s}$.

2. Ermolaev, D.O. (2013) Sotsyalyzatsyia detei s yntellektualnыmy nedostatkamy razvytyia. Fundamentalnie issledovanyia. № 9-1. 32-36. URL: http://www.fundamental-research.ru/ru/article/view?id=32172 (data zvernennia: 29.08.2020).

3. Kapska, A. Y. Sotsialna robota: deiaki aspekty roboty z ditmy ta moloddiu (2001). Kyiv, 21.

4. Moiseiuk, N. (1998) Pedahohika. Vinnytsia: Universum-Vinnytsia. 348 s.

5. Moskalenko V.V. Sotsialna psykholohiia. Kyiv: Tsentr uchbovoi literatury, 2008. 688s.

6. Mosiakova, I. Yu. (2018) Kontseptualni osnovy modernizatsii zmistu pozashkilnoi osvity: praktyko oriientovanyi posibnyk. Kyiv : Pedahohichna dumka. Ch.1. $121 \mathrm{~s}$.

7. Moskalenko, V. V. (2013) Sotsializatsiia osobystosti: monohrafiia. Kyiv : Feniks. 540 s.

8. Mudryk, A.V. (2009) Sotsyalnaia pedahohyka. Moskva : Akademyia. $224 \mathrm{~s}$.

9. Petrochko, Zh. V. (2010) Dytyna v skladnykh zhyttievykh obstavynakh: sotsialno-pedahohichne zabezpechennia prav. Rivne. $368 \mathrm{~s}$.

10.Rean, A. Psykholohyia cheloveka ot rozhdenyia do smerty. Moskva: Yzdatelstvo ACT, 2015. $656 \mathrm{~s}$.

11.Tsyba, V. H. (2000) Sotsiolohiia osobystosti: systemnyi pidkhid (sotsialnopsykholohichnyi analiz). Kyiv : MAUP. 217 s. 